\title{
1 Full title: Production and control of a Brazilian tailor-made meningococcal B vaccine
}

\section{Short title: Brazilian meningococcal B vaccine production}

3 Jessouroun $\mathrm{E}^{1 \mathrm{a}^{*}}$, Santos $\mathrm{AP}^{1 \mathrm{~b}}$, Figueira $\mathrm{ES}^{1 \mathrm{~b}}$, Correa $\mathrm{MB}^{1 \mathrm{~b}}$, \& Leal ML ${ }^{1 \mathrm{~b}}$

$4 \quad{ }^{1}$ Department of Technological Development, Bio-Manguinhos, Fundação Oswaldo Cruz.

5 \#a Current Adreess: Bacterial Vaccines Program, Department of Technological Development, 6 Bio-Manguinhos, Fundação Oswaldo Cruz, Avenida Brasil 4365, Manguinhos, Rio de Janeiro, 7 RJ, CEP 21040-360, Brazil.

8 \#b Current Adreess: Laboratory of Bacterial Technologies, Department of Technological

9 Development, Bio-Manguinhos, Fundação Oswaldo Cruz, Avenida Brasil 4365, Manguinhos, 10 Rio de Janeiro, RJ, CEP 21040-360, Brazil.

12 *Corresponding author: Ellen Jessouroun ${ }^{1}$ Bacterial Vaccines Program, Department of

13 Technological Development, Bio-Manguinhos, Fundação Oswaldo Cruz, Avenida Brasil 4365,

14 Manguinhos, Rio de Janeiro, RJ, CEP 21040-360, Brazil.

15 Tel: 552138829345 , mobile phone: 55219932337144727

16 Email: ellen@bio.fiocruz.br

17 These authors contributed equally to this work. 


\section{Abstract}

19 Meningococcal disease has been a public health problem in Brazil since the serogroups A and

20 C epidemics occurred in the 1970s. The Oswaldo Cruz Foundation in Brazil has been working

21 to develop a serogroup B meningococcal vaccine composed of detergent-treated outer 22 membrane vesicles (OMV) and detoxified endotoxin (dLOS) from Neisseria meningitidis 23 serogroup B prevalent strains. Experimental vaccine were produced in a pilot-scale under Good 24 Manufacturing Practice condition (GMP). Physicochemical and biological controls were established based on what has been reported previously for OMV vaccines. The developed vaccine contained the main class $1,2,3$, and 5 proteins, some minor iron-regulated proteins, and $5-10 \%$ residual lipopolysaccharide related to total protein content. The dLOS was added, as a vaccine component, in half of the total protein amount. The pyrogenicity of the final products, based on the residual LOS in OMVs, varied from 1.01 to $2.24 \mathrm{ng} \mathrm{LOS} / \mathrm{kg}$ rabbit. Three experimental vaccines, were highly immunogenic in mice with better performance using higher antigen concentrations.

Keywords: Meningococcal disease 
37

\section{INTRODUCTION}

Meningococcal disease remains a worldwide health problem and has been a public health problem in Brazil since the groups A and C epidemics of the 1970s. Serogroup B caused $80 \%$ of the meningococcal disease cases throughout the 1980s with a significant number of cases in children $<2$-years-of-age $[1,2]$.

The, B:4,7:P1.19,15, L3,7,8 phenotype was responsible for the 1988 São Paulo epidemic, continued to represent the predominant B phenotype from 2000 to 2004, and seems to be the main strain today $[3,4]$.

The other prevailing phenotypes identified were B:4,7:P1.7, L3,7 and B:15:P1.7,16, which have high frequencies in the southern states of Brazil. These three prevalent serosubtypes belong to the same ET-5 electrophoretic type [5].

The emergence of W135, which is associated with the ST-11 complex, was reported in São Paulo, Rio de Janeiro, and Rio Grande do Sul. Serogroup C was responsible for $75 \%$ of the cases identified in $2010,17 \%$ by serogroup B, $6 \%$ by serogroup W135, and $2 \%$ for serogroup $\mathrm{Y}[1]$.

The Brazilian Ministry of Health decided the use a Cuban vaccine (VAMENGOC-BC®) in the southern region of Brazil in the 1990s when they were trying to control the meningococcal B epidemic. Case control studies to estimate vaccine efficacy in Brazil were performed from 1989 to 1990 . The results indicate that the vaccine generally did not provide protection against heterologous strains and only induced modest protection in young children $[6,7,8]$.

Based on the results of the use of the Cuban vaccine in Brazil, three Brazilian research institutions (Bio-Manguinhos/Fiocruz, Institutos Butantan, and Adolfo Lutz) have collaborated to develop a serogroup B meningococcal vaccine composed of detergent-treated OMVs and 
60 detoxified lipooligosaccharide (dLOS) from Brazilian prevalent strains. The Brazilian

61 approach has focused on developing a tailor-made vaccine that have been developed and

62 successfully proven efficacious against serogroup B meningococcal disease in Cuba, Norway,

63 and New Zealand. The inclusion of dLOS as a vaccine component, was based on the fact that

64 other subcapsular antigens, in addition to OMV, may benefit cross-immunitity within different

65 serotypes of meningo B strains $[9,10]$.

66 Preliminary pre-clinical data showed animal protection induction of experimental vaccines

67 from an intraperitoneal challenge model in mice, and protective bactericidal antibody against

68 vaccine strains [11].

69 The study presented here describes a vaccine standardized production and control under Good 70 Manufacturing Practice (GMP) conditions in a pilot-scale process. The results indicate 71 production and controls compatible with OMV vaccines and potential use of the developed product for clinical studies for safety and immunogenicity assessment [12,13].

MATERIAL AND METHODS

\section{VACCINE PREPARATION}

\section{VACCINE STRAINS} by the Adolfo Lutz Institute, São Paulo, Brazil.

\section{BIOMASS HARVEST}

The production process included cultivation of the vaccine strains in a $150 \mathrm{~L}$ bioreactor (B 
diamine-di-(O-hydroxy-phenylacetic acid) (EDDHA) to produce the OMVs.

Lipooligosaccharide (LOS) was produced in the same way described for OMVs without EDDHA. Bacterial growth was inactivated with heat $\left(56^{\circ} \mathrm{C} / 30 \mathrm{~min}\right)$, and the biomass was separated by continuous flow centrifugation (LAPX 4045GP-31G; Alfa Laval) [14].

\section{OMV ANTIGENS}

The LOS-depleted OMVs were obtained from the culture supernatant, and concentrated by tangential ultrafiltration in a Centrasette stainless steel cassette holder using a polyethersulfone Centrasette cassette $\left(0.9-\mathrm{m}^{2}\right)$ and a molecular weight cutoff of $100 \mathrm{kDa}$ (Pall Corp., Port Washington, NY, USA). The concentrate was treated with 2\% (w/v) sodium desoxycholate (DOC) and LOS-depleted OMVs were harvested by ultracentrifugation $(100,000 \mathrm{~g}$ for $2 \mathrm{~h})$, in water for injection containing $3 \%$ sterile-filtered sucrose using a $0.22-\mu \mathrm{m}$ Millipak $^{\circledR}-200$ polyvinylidene fluoride membrane (PVDF; Millipore, Billerica, MA, USA) [11].

\section{DETOXIFIED LOS ANTIGEN}

LOS from N44/89 strain, was obtained from the culture biomass after hexadecyl trimethyl ammonium bromide (Cetavlon-Fluka Analytical code 52370) treatment using the hot phenol/water method (Gotschlich,1969; Westphal,1965). The extracted LOS was further purified by gel filtration chromatography using $20 \mathrm{mM}$ Tris- $\mathrm{HCl}, \mathrm{pH} 8.5$, containing $0.5 \%$ DOC and $5 \mathrm{mM}$ EDTA as the mobile phase on a single Sephacryl HR S-300 column (ID: $5.0 \mu \mathrm{m} \mathrm{L}$ : $100.0 \mathrm{~cm})$. The LOS sample solution applied to the column was limited to $4 \%$ of bed volume and a LOS mass not greater than $600 \mathrm{mg}$ [15].The detoxified LOS (dLOS) was obtained by treatment of raw material with $0.20 \mathrm{M} \mathrm{NaOH}$ in a water bath at $60^{\circ} \mathrm{C}$ for 150 min $[16,17]$. 


\section{VACCINE FORMULATION}

103

104

Vaccine 1: $[25 \mu \mathrm{g}$ OMV protein $(12.5 \mu \mathrm{g}$ from $\mathrm{N} 44 / 89+12.5 \mu \mathrm{g}$ from $\mathrm{N} 603 / 95+12.5 \mu \mathrm{g}$ dLOS from $\left.\mathrm{N} 44 / 89)+\mathrm{Al}(\mathrm{OH})_{3} / 2 \mathrm{mg} / \mathrm{mL}\right]$.Vaccine 2: [50 $\mu \mathrm{g}$ OMV protein $(25 \mu \mathrm{g}$ from N44/89 $+25 \mu \mathrm{g}$ from $\mathrm{N} 603 / 95+25 \mu \mathrm{g}$ of dLOS from $\left.\mathrm{N} 44 / 89+\mathrm{Al}(\mathrm{OH})_{3} / 2 \mathrm{mg} / \mathrm{mL}\right]$. Vaccine 3: [100 $\mu \mathrm{g}$ OMV protein $(50 \mu \mathrm{g}$ from N44/89 $+50 \mu \mathrm{g}$ from N603/95 $+50 \mu \mathrm{g}$ of dLOS from N44/89 + $\mathrm{Al}(\mathrm{OH})_{3} / 2 \mathrm{mg} / \mathrm{mL}$. The final quality control tests were performed in the Quality Control Department of Bio-Manguinhos (Rio de Janeiro, Brazil). Vamengoc BC $($ and DTP vaccine as the reference in pyrogen test .

\section{VACCINE RESPONSE STUDIES}

\section{STUDY GROUPS}

Swiss Webster male and female mice (weight, 12-17 g) were obtained from Oswaldo Cruz Foundation breeding unit (Rio de Janeiro, Brazil) and caged with free access to food and water in a room maintained at $22-24^{\circ} \mathrm{C}$ with a $12 \mathrm{~h}: 12 \mathrm{~h}$ light/dark cycle in the Bio-Manguinhos Experimental Animal Facility. The animal procedures were conducted according to the Oswaldo Cruz Foundation Ethical Committee for animal using (CEUA/FIOCRUZ number LW65/14). Groups of 15 mice were immunized intramuscularly with $0.2 \mathrm{~mL}$ of the final experimental product (diluted 1:10 in phosphate buffered solution (PBS). A three-dose immunization schedule of 14 days intervals was used. Groups of five mice were bled (retroorbital via) before each dose and 15 days after the third immunization.

\section{OMV-ENZYME-LINKED IMMUNOSORBENT ASSAY (ELISA)}

To detect anti-OMV total IgG, 96-well plates (ref. no. 3590; Corning-Costar, Corning, NY, USA) were coated with $100 \mu \mathrm{L} /$ well of OMV (4 $\mu \mathrm{g} / \mathrm{mL})$ from N44/89 or N603/95 strains. Sera 
samples were diluted in two-fold serial dilutions in TBS with $0.05 \%$ Tween 20 (Merck,

127 phosphatase (whole molecule) (Sigma-Aldrich A-3688) diluted 1:2000. All sera were titrated in duplicate, and the titers were determined at an absorbance of $405 \mathrm{~nm}$ using a VERSA max tunable microplate reader (Molecular Devices, Sunnyvale, CA, USA). As the antibody standard, a positive post vaccination serum was used in all experiments. The observed optical density was transformed to arbitrary units per milliliter by a sigmoidal standard curve (logit$\log$ transformation) calculated from the values $(1000 \mathrm{EU} / \mathrm{mL})$ of the reference serum [18].

\section{LOS ELISA ASSAY} overnight at room temperature with $100 \mu \mathrm{L} /$ well of $10 \mu \mathrm{g} / \mathrm{mL}$ LOS-DOC micelles dissolved in PBS with $0.1 \%$ DOC. TBS with 5\% bovine serum albumin (BSA) (Sigma-Aldrich ref A9418) was used as the blocking buffer for $2 \mathrm{~h}$ at $37^{\circ} \mathrm{C}$. Sera samples were titrated in duplicate in TBS with 5\% BSA and incubated for $3 \mathrm{~h}$ at $37^{\circ} \mathrm{C}$. Conjugated antibodies (Sigma-Aldrich A-3688) were diluted 1:1000 and incubated for $2 \mathrm{~h}$ at $37^{\circ} \mathrm{C}$. The reaction was developed for $20 \mathrm{~min}$ with a phosphatase substrate (Sigma-Aldrich S0942). All sera were titrated in duplicate and titers were determined with absorbance at $405 \mathrm{~nm}$ in VERSAmax tunable microplate reader Molecular Devices. The total $\mathrm{IgG}$ antibody responses (EU/mL) against OMVs and LOS, were presented as geometric mean concentrations (GMC) of five serum samples (pool of five mice)

144 by using a 4-parameter logistic curve-fitting analysis with SoftMaxPro software and documentation - Molecular Devices, against the standard curve generated by in-house serum with $1000 \mathrm{EU} / \mathrm{mL}$ of arbitrary units. All p-values were calculated with Kruskall Wallis test. 


\section{SERUM BACTERICIDAL ASSAY (SBA)}

The bacterial strains, was streaked on Columbia blood agar (Merck 1.10455.0500), plated with $5 \%$ horse blood (CBA), and incubated overnight at $37^{\circ} \mathrm{C}$ in $5 \% \mathrm{CO}_{2}$. The next morning, $10-20$ colonies, were subculture on another CBA plate and incubated for $4 \mathrm{~h}$ at $37^{\circ} \mathrm{C}$ in $5 \% \mathrm{CO}_{2}$. After $4 \mathrm{~h}$, the bacteria were suspended in a bactericidal buffer (Hanks balanced salt solution) containing 0.5\% BSA (Sigma, Poole, UK) and $0.5 \mathrm{U} / \mathrm{mL}$ heparin (CP Pharmaceuticals, Wrexham, UK). The bacteria concentration was adjusted to $2 \times 10^{5}$ colony forming units $(\mathrm{cfu}) / \mathrm{mL}$. Equal volumes $(10 \mu \mathrm{L})$ of the bacterial suspension and human complement were added to $20 \mu \mathrm{L}$ heat-inactivated test serum serially diluted two-fold in bactericidal buffer and added to 96-well U-bottom microtiter plates (Greiner, Frickenhausen, Germany). Human plasma from a suitable donor (Research Ethics Committee, Hemorio Hospital, Rio de Janeiro, Brazil No. 118/07) was used as the complement source. The plasma was used in the assay after a 60 min incubation at $25 \%$ of the final concentration. The number of bacteria was determined at time zero, by allowing $10 \mu \mathrm{L}$ of the reaction mixture to flow $8-10 \mathrm{~cm}$ in lanes down a CBA plate (the tilt method). After a 60 -min incubation of the reaction mixture at $37^{\circ} \mathrm{C}, 10 \mu \mathrm{L}$ was removed from each well and plated on CBA. The colonies were counted after a $37^{\circ} \mathrm{C}$ overnight incubation in $5 \% \mathrm{CO}_{2}$. SBA titers were expressed as the reciprocal of the final serum dilution step that produces a $50 \%$ mortality after 60 min compared to the number of bacteria at time zero. Three in-house control sera (low, medium, and high titers) were used as controls for the assays in each target strain. The test was performed using vaccine strains as the target [20,21].

\section{TEST FOR TOXICITY}

The experimental vaccines were tested by intraperitoneal injection of one human dose, but not more than $1 \mathrm{~mL}$ of experimental vaccine into 5 mice (weight, 17-22 g) diluted in diluent. Two guinea pigs (weight, 250-350 g) were also injected (i.p.) with the equivalent of 10 human doses 
in a volume $<5 \mathrm{~mL}$. The vaccines tested were considered innocuous if the animals survived at least 7 days without showing significant toxic signs. Cuban (VAMENGOC-BC ${ }^{\circledR}$ ) and DTP

174 (Butantan Institute, São Paulo, Brazil) were used as the reference of licensed vaccines for 175 human use, in Brazil [22].

\section{RABBIT PYROGEN TEST}

Briefly, the tested vaccines in various human-dose dilutions were given intravenously to three rabbits (weight, $2.5-3.0 \mathrm{~kg}$ ) at a rate of $1 \mathrm{~mL} / \mathrm{kg}$ of rabbit body weight. Cuban (VAMENGOC$\mathrm{BC}^{\circledR}$ ) and DTP (Butantan Institute, São Paulo, Brazil) were used as a reference of licensed vaccines for human use, in Brazil. Rectal temperature was measured with an indwelling rectal thermometer and recorded $5 \mathrm{~h}$ after injecting the sample. The preparations were considered approved if the summed temperature variations of the three rabbits did not exceed $1.15^{\circ} \mathrm{C}[22]$.

\section{STERILITY TEST}

According to the European Pharmacopoeia, eight vials of each vaccine containing five doses each in $\mathrm{Al}(\mathrm{OH})_{3}$ vaccine diluent, pooled, and filtered through a $0.22-\mu \mathrm{m}$ PVDF membrane to fluidize the thioglycolate (TGC) and soy-bean casein media (TSB). The TGC and TSB were incubated at $30-35^{\circ} \mathrm{C}$ for $24-48 \mathrm{~h}$ and $20-25^{\circ} \mathrm{C}$ for $10-15$ days, respectively [23].

\section{PhysicoChemical Controls}

\section{Protein Concentration}

Briefly, the OMVs were mixed in the copper reagent $\left(4 \% \mathrm{CuSO}_{4} \cdot 5 \mathrm{H}_{2} \mathrm{O}\right)$ with sodium dodecyl 
determined in Beckman DU530 spectrophotometer at $660 \mathrm{~nm}$ against a BSA standard curve

194 (Pierce, Rockford, IL, USA) [24].

SODIUM DODECYL SULFATE-POLYACRYLAMIDE GEL ELECTROPHORESIS (SDS-PAGE)

PATTERN

The protein profile of the OMV preparations, before vaccine formulation,was analyzed by $12 \%$ PAGE in the presence of $2 \%(\mathrm{w} / \mathrm{v})$ SDS. The proteins were stained with $0.1 \%(\mathrm{w} / \mathrm{v})$ Coomassie Brilliant Blue, and analyzed by densitometry. The stained class protein bands were determined by scanning the gel, the relative amount of each protein was calculated using Quantity One software (densitometer GS-800; Bio-Rad Laboratories, Hercules, CA, USA), and was presented as a percentage of total protein [25].

\section{LOS AND dLOS ELECTROPHORESIS PATTERN}

The LOS samples (LOS and dLOS) were treated for $5 \mathrm{~min}$ at $100^{\circ} \mathrm{C}$ in $0.05 \mathrm{M}$ Tris- $\mathrm{HCl}$ buffer (pH 6.8), 2\% (w/v) SDS, 10\% (w/v) sucrose, and $0.01 \%$ bromophenol blue and fractionated on an SDS-polyacrylamide gel $(8 \times 7.3 \mathrm{~cm}$ by $0.75 \mathrm{~mm})$ containing $4 \%$ and $16.5 \%$ acrylamide in the stacking and separating gels, respectively. The electrophoresis was performed at $15 \mathrm{~mA}$ in the stacking gel and $20 \mathrm{~mA}$ in the separating gel until the tracking dye had traveled about 10 $\mathrm{cm}$. The SDS-PAGE fractionated LOS preparation was stained using the conventional silver staining method of Tsai and Frasch, 1982. A protein standard $(16,949-2,512 \mathrm{kDa})$ was used to estimate the molecular weights of LOS and dLOS. The gel was stained with $0.1 \%(\mathrm{w} / \mathrm{v})$ Coomassie Brilliant Blue [26]. HP Scanjet G4050 Scanner was used, to scan the gel, with the following parameters: Output Type: Gray Scale; File Type: Unzipped Tif (* .tif) image; Output Resolution: 1200 dpi (dot per inch). The gel image file was analyzed using the Image Master 1D Prime V3.01 software (Pharmacia Biotech, San Francisco, CA, USA) 


\section{STRUCTURAL ChARACTERIZATION OF dLOS}

217 Detoxified LOS, which is $O$-deacylated (dLOS), was hydrolyzed in acetate buffer at $\mathrm{pH}$ 4.5. It

218 was purified by gel-filtration chromatography using a Bio-Gel P-4 column. The dLOS

219 electrospray ionization/mass spectroscopy analysis was performed with a Thermo Finnigan LCQ Deca XP ion trap mass spectrometer (ThermoScientific, Waltham, MA, USA). Capillary temperature was $200^{\circ} \mathrm{C}$, capillary voltage was $45 \mathrm{KV}$, and mass range $\mathrm{m} / \mathrm{z}$ was $250-2000$ [27].

\section{RESIDUAL LOS in THE OMV PREPARATIONS}

LOS was quantified by determining 2-keto-3-deoxyoctonic acid (KDO) content using a mass conversion factor value of 20 . OMVs from each strain, were diluted in $1 \mathrm{M}$ Tris- $\mathrm{HCl}, 0.5 \%$ SDS, and $0.05 \mathrm{M} \mathrm{CaCl}_{2}$ buffer, at $\mathrm{pH} 7.5$ following incubation for $5 \mathrm{~min}$ at $100^{\circ} \mathrm{C}$. The protein in this suspension was digested with proteinase $\mathrm{K}$ for $4 \mathrm{~h}$ at $56^{\circ} \mathrm{C} . \mathrm{KDO}$ content was measured using the thiobarbituric acid procedure. Briefly, a standard aqueous $(0.1 \mathrm{mg} / \mathrm{mL})$ solution of KDO (Sigma ref K2755) was prepared and stored at $-20^{\circ} \mathrm{C}$. This standard solution was diluted to prepare five different concentrations. The digested samples were hydrolyzed in trifluoracetic acid and treated in sequence with periodic acid, sodium arsenite, and thiobarbituric acid and a KDO standard curve [28].

$\mathrm{pH}$ was determined in each experimental vaccine in its diluent according to the United States 
The quantity of sucrose in the experimental vaccines diluted in water was analyzed by highperformance liquid chromatography (HPLC; Waters, Milford, MA, USA) using a Shodex Sugar SC1011 column $(300 \times 8 \mathrm{~mm})$ at $75^{\circ} \mathrm{C}$ and degasified Milli-Q water as the mobile phase at a

242 flow rate of $0.8 \mathrm{~mL} / \mathrm{min}$. The sucrose amount was evaluated with a refractive index detector 243 (Waters IR 410 Channel 2) [29].

\section{Aluminum hydroxide adsorption}

The experimental vaccines were centrifuged $\left(4,000 \mathrm{rpm} / 20 \mathrm{~min} / 4^{\circ} \mathrm{C}\right)$, and protein content was measured in the supernatant. The test was verified by $>80 \%$ adsorption of the total vaccine protein concentration [22].

\section{Electron microscopy}

Droplets of LOS-depleted OMVs from the N44/89 strain (1 mg protein/mL) in distilled water

were applied to glow-discharged, carbon-filmed grids for 1 min and negatively stained with $0.5 \%(\mathrm{w} / \mathrm{v})$ phosphotungstic acid, $\mathrm{pH} 7.0$ for $1 \mathrm{~min}$. The preparations were examined under an electron microscope operated at $100 \mathrm{keV}$ (JEM 1010; Jeol, Tokyo, Japan) [30].

\section{Sialic acid content}

Residual sialic acid was quantified by HPLC using a pulsed amperometric detector. Before HPLC, the OMV DOC treated, was hydrolyzed with $0.2 \mathrm{M} \mathrm{HCl}$ at $100^{\circ} \mathrm{C}$ for $60 \mathrm{~min}$. HPLC analyses were performed on a Dionex I.C.S.-3000i, with a LC50 gradient pump and an ED50 electrochemical detector with a gold working electrode. A borate trap was used for the mobile phase followed by an amino trap for sample clean up. The analysis was performed using a Carbopac PA10 guard and analytical column. Data were acquired, based on the standard $N$ acetyl neuraminic acid peak at $5.1 \mathrm{~min}$. The mobile phase was $0.1 \mathrm{M} \mathrm{NaOH}: 0.1 \mathrm{M}$ sodium acetate (45:55) at a flow rate of $0.8 \mathrm{~mL} / \mathrm{min}$. Total run time was $30 \mathrm{~min}$ [31]. 
262 Aluminum content

263 Aluminum from the experimental vaccines was evaluated accordingly to European

264 Pharmacopoeia [32].

\section{Statistical analysis}

266 The Kruskal-Wallis test was used to evaluate differences between the experimental vaccines 0

267 (before vaccination) and 15 days after the last dose. Differences were considered significant at $268 \mathrm{p}<0.05$. The ELISA and SBA data of the two strains were compared with the Mann-Whitney 269 test. All data were analyzed using Statgraphics Plus Professional ver. 4.1 software 270 (Statgraphics, Warrenton, VA, USA).

\section{RESULTS}

\section{PHYSICOCHEMICAL CONTROLS}

273 The experimental formulations were sterile, more than $80 \%$ of vaccine antigens adsorbed in $\mathrm{Al}$

$274(\mathrm{OH})_{3}$, had appropriate $\mathrm{pH}$, sialic acid, aluminum, and antigen concentrations in accordance

275 with the established quantitative limits. The OMVs in residual LOS varied from 5 to $10 \%$ of 276 the OMV protein (Table 1). 
Table 1-Physicochemical and biological controls for the tested vaccines.

\begin{tabular}{|c|c|c|c|c|c|}
\hline Test & Control method & Quantitative limits & Vaccine $1^{a}$ & Vaccine $2^{b}$ & Vaccine 3 \\
\hline Protein $(\mu \mathrm{g} / \mathrm{mL})$ & Modified Folin-Lowry & Protein content $( \pm 10 \%)$ & 23.6 & 47.4 & 98.53 \\
\hline $\mathrm{dLOS}(\mu \mathrm{g} / \mathrm{mL})$ & Osborn & dLOS content $( \pm 10 \%)$ & 12.5 & 25 & 50 \\
\hline Residual LOS $(\mu \mathrm{g} / 100 \mu \mathrm{g}$ ptn $)$ & Osborn & $5-10$ & 4.3 & 4.3 & 4.55 \\
\hline $\begin{array}{c}\text { Group B polysaccharide }(\mu \mathrm{g} / 100 \mu \mathrm{g} \\
\text { ptn) }\end{array}$ & HPI-PAD & $<0.25$ & 0.01 & 0.01 & 0.01 \\
\hline Aluminum $(\mathrm{mg} / \mathrm{mL})$ & Atomic adsorption & $<1.25$ & 0.76 & 0.78 & 0.85 \\
\hline Identity & Dot-Blot assay & $\begin{array}{l}\text { Reactivity with specific } \\
\text { monoclonal antibody }\end{array}$ & Pass & Pass & Pass \\
\hline Antigen standard & SDS-PAGE & $\begin{array}{c}\text { 60-90 kDa: } 13-21 \% \\
\text { Class 1: } 13-17 \% \\
\text { Class 3: } 22-35 \% \\
\text { Class 4: } 6-16 \% \\
\text { Class 5: } 7-14 \%\end{array}$ & Pass & Pass & Pass \\
\hline Degree of binding to adjuvant (\%) & Modified Folin-Lowry & $>80$ & 94.5 & 94.8 & 98.53 \\
\hline Sucrose $(\mathrm{mg} / \mathrm{mL})$ & HPLC & $26-38$ & 30.52 & 29.94 & 29.5 \\
\hline $\mathrm{pH}$ & Determination by $\mathrm{pH}-$ meter & $6.5-7.8$ & 7.1 & 7.1 & 7.2 \\
\hline Sterility testing & $\begin{array}{l}\text { Membrane-filtration method } \\
\text { (Ph. Eur.) }\end{array}$ & Pass & Pass & Pass & Pass \\
\hline Abnormal toxicity & $\begin{array}{l}\text { Safety test } \\
\text { (Ph. Eur.) }\end{array}$ & Pass & Pass & Pass & Pass \\
\hline Pyrogenicity & Rabbit method & $\leq 1: 4000$ & $1: 1000$ & $1: 1000$ & $1: 2000$ \\
\hline $\begin{array}{c}\text { Dilution } \\
\text { (ng protein/Kg rabbit) }\end{array}$ & & Pass & 23.6 & 47.4 & 49.3 \\
\hline
\end{tabular}


282 The base peak was identified as a multiple-charge ion $\left[\mathrm{M}+2 \mathrm{H}-\mathrm{H}_{2} \mathrm{O}\right]^{+2}$ at $\mathrm{m} / \mathrm{z} 1387.9$, after

283 charge deconvolution, showed molecular weight compatible with a dihexosamine backbone,

284 carrying 1,4' diphosphate groups (PP) and N,N-diacylated by 3-hydroxy-tetradecanoyl fatty

285 chains. No variation of mass was observed for OS core moiety, (Figure 1).

286 Figure 1: Electrospray ionization/mass spectroscopy (ESI/MS) of O-deacylated

287 lipooligosaccharide (LOS) from N44/89 Neisseria meningitidis B, strain.

288 A second minority ion was also analyzed. A sodiated-protonated ion $[\mathrm{M}+\mathrm{H}+\mathrm{Na}]^{+2}$ at $\mathrm{m} / \mathrm{z}$ 289 1367.87. It had mass compatible with a diacylated lipid A and OS core discribled previously 290 (m/z 1387.9), but differs in their phospho groups, showing only a monophosphorylated (P) 291 form. Native LOS was also analyzed showing molecular weight compatible with and 292 hexacylated structure carrying two units of phosphoethanolamine (data not shown).

\section{MORPHOLOGY}

294 The morphology of the final N44/89 preparation obtained by electron microscopy is presented 295 in Figure 2. The OMV range in size and morphology after sterile filtration were around 80-100 $296 \mathrm{~nm}$.

297 Figure 2: Electron microscopy of outer membrane vesicles (OMV) from the N44/89 strain (1 $298 \mathrm{mg} / \mathrm{mL})$ in distilled water negatively stained with $0.5 \%(\mathrm{w} / \mathrm{v})$ phosphotungstic acid, $\mathrm{pH} 7.0$ The preparations were examined under an electron microscope (JEM 1010; Jeol, Tokyo, Japan). 


\section{Biological Controls}

302 The three experimental vaccines induced significant increases in total $\operatorname{IgG}(\mathrm{p}<0.001)$ in

303 response to the OMVs (Table 2) of both Brazilian prevalent strains with no difference between

304 them. Seroconversion to $\operatorname{LOS}$ (300 and 1,000-fold) was detected 15 days after the third dose

305 for vaccines 2 and 3 , respectively. 
Table 2: Total IgG geometric mean concentrations (GMCs) against vaccine components from the N44/89 and N603/95 strains before and after immunizing mice with three doses of a vaccine as determined by enzyme-linked immunosorbent assay.

Mice total antibody by ELISA against OMVs from strains N44/89 and N603/95 and LOS from N44/89 strain

\begin{tabular}{|c|c|c|c|c|c|c|c|c|c|}
\hline \multirow[t]{2}{*}{ Study time } & \multicolumn{3}{|c|}{$\mathrm{N} 44 / 89(\mathrm{~B}: 4,7: \mathrm{P} 1.19,15, \mathrm{~L} 1,3,7,8)^{\mathrm{d}}$} & \multicolumn{3}{|c|}{ N603/95(B:4:P1,7,1, L,3,7)e } & \multicolumn{3}{|c|}{ LOS (B:4,7:P1.19,15, L1,3,7,8)f } \\
\hline & $25 \mu \mathrm{g} / \mathrm{mL}^{\mathrm{a}}$ & $50 \mu \mathrm{g} / \mathrm{mL}^{\mathrm{b}}$ & $100 \mu \mathrm{g} / \mathrm{mL}^{\mathrm{c}}$ & $25 \mu \mathrm{g} / \mathrm{mL}^{\mathrm{a}}$ & $50 \mu \mathrm{g} / \mathrm{mL}^{\mathrm{b}}$ & $100 \mu \mathrm{g} / \mathrm{mL}^{\mathrm{c}}$ & $25 \mu \mathrm{g} / \mathrm{mL}^{\mathrm{a}}$ & $50 \mu \mathrm{g} / \mathrm{mL}^{\mathrm{b}}$ & $100 \mu \mathrm{g} / \mathrm{mL}^{\mathrm{c}}$ \\
\hline Day 0 & $<\mathrm{DL}$ & $<\mathrm{DL}$ & $<\mathrm{DL}$ & $<\mathrm{DL}$ & $<\mathrm{DL}$ & $<\mathrm{DL}$ & $<\mathrm{DL}$ & $<\mathrm{DL}$ & $<\mathrm{DL}$ \\
\hline $\begin{array}{c}\text { Before } 2^{\text {nd }} \\
\text { dose (Day 15) }\end{array}$ & $263 \pm 32$ & $868 \pm 40$ & $185 \pm 40$ & $113 \pm 8.28$ & $446 \pm 44$ & $448 \pm 12$ & $<\mathrm{DL}$ & $<\mathrm{DL}$ & $<\mathrm{DL}$ \\
\hline $\begin{array}{c}\text { Before } 3^{\text {rd }} \\
\text { dose (Day 30) }\end{array}$ & $3508 \pm 339$ & $7027 \pm 182$ & $11596 \pm 649$ & $4128 \pm 478$ & $7008 \pm 215$ & $11061 \pm 253$ & $<\mathrm{DL}$ & $<\mathrm{DL}$ & $<\mathrm{DL}$ \\
\hline $\begin{array}{c}\text { After } 3^{\text {rd }} \text { dose } \\
\text { (Day 45) }\end{array}$ & $\begin{array}{c}14946 \pm 1 \\
138\end{array}$ & $8415 \pm 497$ & $16262 \pm 191$ & $14368 \pm 115$ & $11781 \pm 203$ & $10279 \pm 243$ & $<\mathrm{DL}$ & $334.6 \pm 16.5$ & $1002 \pm 142.3$ \\
\hline
\end{tabular}

309 aVaccine 1: $25 \mu \mathrm{g}$ OMV protein $(\mathrm{N} 44 / 89+\mathrm{N} 603 / 95)+12.5 \mu \mathrm{g}$ detoxified endotoxin $(\mathrm{dLOS})+2 \mathrm{mg} \mathrm{Al}(\mathrm{OH})_{3} / \mathrm{mL}$

310 bVaccine 2: $50 \mu \mathrm{g}$ OMV protein (N44/89 + N603/95) + $25 \mu \mathrm{g}$ dLOS $+2 \mathrm{mg} \mathrm{Al}(\mathrm{OH})_{3} / \mathrm{mL}$

311 'Vaccine 3: $100 \mu \mathrm{g}$ OMV protein (N44/89 + N603/95) + $50 \mu \mathrm{g} \mathrm{dLOS}+2 \mathrm{mg} \mathrm{Al}(\mathrm{OH})_{3} / \mathrm{mL}$

312 dOMV from N44/89 as coating antigen; ${ }^{\mathrm{C}} \mathrm{OMV}$ from N603/95; $\mathrm{LOS}^{\mathrm{f}}$ as coating antigen.

$313 \mathrm{~g}^{\circ}$ of subjects: three pools of five mice each in the indicated group: GMC \pm standard error; $\mathrm{NE}-$ non-evaluated; $<\mathrm{DL}$ below detection limit. 
315 Vaccine 1 did not induce a LOS response in mice at the same evaluation time, suggesting that

316 the immune antigen response was concentration dependent. Considering a fourfold increase in

317 bactericidal titres, after 3 doses of vaccines as a immunogenicity parameter, the experimental

318 vaccines were very immunogenic in mice. The response for N44/89 strain was stronger than for

319 N603/95 even in the vaccine with the lowest concentration of vaccine components. Based on

320 the bactericidal activity of pre immune sera, the response to N44/89 was 4 and 8 times higher

321 than N603/95 in the intermediate and maximum antigen vaccines concentration, respectively.

322 In addition, the bactericidal titers were significantly higher for N44/89 than what was observed

323 to N603/95 after the third dose (Table 3). 
Table 3: Serum bactericidal assay (SBA) antibody titers (reciprocal serum dilution $\geq 50 \%$ killing) against group B vaccine strains before and after immunizing mice with a three-dose vaccination schedule using phase II trial meningococcal experimental vaccines.

Bactericidal titers indicated as reciprocal sera dilution $\geq 50 \%$ killing $^{\mathrm{a}}$

\begin{tabular}{|c|c|c|c|c|c|c|}
\hline Study time point & \multicolumn{3}{|c|}{$\mathrm{N} 44 / 89(\mathrm{~B}: 4,7: \mathrm{P} 1.19,15: \mathrm{P} 5.5,7: \mathrm{L} 1,3,7,8)^{\mathrm{e}}$} & \multicolumn{3}{|c|}{ N603/95(B:4:P1,7,1: P5.5,7: L,3,7) } \\
\hline \multicolumn{7}{|l|}{ Experimental } \\
\hline & $25 \mu \mathrm{g} / \mathrm{mL}^{\mathrm{b}}$ & $50 \mu \mathrm{g} / \mathrm{mL}^{\mathrm{c}}$ & $100 \mu \mathrm{g} / \mathrm{mL}^{\mathrm{d}}$ & $25 \mu \mathrm{g} / \mathrm{mL}^{\mathrm{b}}$ & $50 \mu \mathrm{g} / \mathrm{mL}^{\mathrm{c}}$ & $100 \mu \mathrm{g} / \mathrm{mL}^{\mathrm{d}}$ \\
\hline \multicolumn{7}{|l|}{ Vaccines } \\
\hline \multicolumn{7}{|l|}{ Pre-immune sera } \\
\hline \multicolumn{7}{|l|}{ (Day 0 ) } \\
\hline After $3^{\text {rd }}$ dose & 256 & 256 & 512 & 2 & 64 & 64 \\
\hline (Day 45) & $(128-256)$ & $(128-256)$ & $(256-512)$ & $(2-2)$ & $(32-64)$ & $(32-04)$ \\
\hline
\end{tabular}

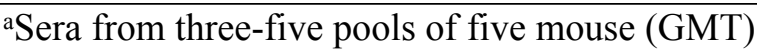

${ }^{\mathrm{b}}$ Vaccine 1: $25 \mu \mathrm{g}$ OMV protein $(\mathrm{N} 44 / 89+\mathrm{N} 603 / 95)+12.5 \mu \mathrm{g}$ detoxified endotoxin $(\mathrm{dLOS})+2 \mathrm{mg} \mathrm{Al}(\mathrm{OH})_{3} / \mathrm{mL}$

${ }^{c}$ Vaccine 2: $50 \mu \mathrm{g}$ OMV protein $(\mathrm{N} 44 / 89+\mathrm{N} 603 / 95)+25 \mu \mathrm{g} \mathrm{dLOS}+2 \mathrm{mg} \mathrm{Al}(\mathrm{OH})_{3} / \mathrm{mL}$

${ }^{d}$ Vaccine 3: $100 \mu \mathrm{g}$ OMV protein $(\mathrm{N} 44 / 89+\mathrm{N} 603 / 95)+50 \mu \mathrm{g} \mathrm{dLOS}+2 \mathrm{mg} \mathrm{Al}(\mathrm{OH})_{3} / \mathrm{mL}$

eN44/89 as SBA target strain.

f N603/95 as SBA target strain 


\section{TOXICITY AND PYROGENICITY}

336 Both mice and guinea pigs survived to 7 days of time observation without any sign of toxicity,

337 such weight loss, due to experimental preparations and reference vaccines administration.

338 According to the WHO requirements for polysaccharide vaccines against $N$. meningitidis, the

339 final product should not induce fever in rabbits at a 1:4,000 dilution of the human dose.

340 Vaccines with 25 and $50 \mu \mathrm{g}$ protein $/ \mathrm{mL}$ were approved in rabbits when the human dose was

341 diluted to 1:1,000. A vaccine with $100 \mu \mathrm{g}$ protein $/ \mathrm{mL}$ was approved in rabbits diluted 1:2,000

342 of the human dose. Cuban and DTP vaccines were approved in 1:4000 of human dose. In

343 terms of minimum pyrogenic dose based on protein amount, the experimental preparations 1 ,

3442 and 3, were respectively $23,6,47,4$ and $49,3 \mathrm{ng}$ of protein per $\mathrm{kg}$ of rabbit. The reference

345 vaccines were $12,5 \mathrm{ng}$ of protein per $\mathrm{kg}$ of rabbit for VAMENGOC-BC ${ }^{\circledR}$ and the DTP

346 vaccines. The experimental vaccines were less pyrogenic than the references. Raw and dLOS,

347 were tested in the rabbit pyrogen test at the highest quantity of the third $(50 \mu \mathrm{g} / \mathrm{mL})$

348 experimental vaccine. After a $30 \mathrm{~min} \mathrm{NaOH}$ treatment, a sharp fall in pyrogenicity of the raw

349 LOS was detected. The dLOS samples from the 120 and 150 min treatments were approved

350 by the rabbit pyrogen test at dilutions of 1:200 and 1:100, respectively (Table 4). 
Table 4: Vaccines toxicity and "in vivo" pyrogen test.

\begin{tabular}{|c|c|c|}
\hline Tested formulation & Abnormal Toxicity ${ }^{\mathrm{a}}$ & "In vivo" pyrogen test ${ }^{\mathrm{b}}$. \\
\hline $\begin{array}{c}\text { Vaccine } 01^{\mathrm{c}} \\
\text { Dilution } \\
\text { ng OMV protein/ Kg rabbit }\end{array}$ & Pass & $\begin{array}{l}\text { Pass } \\
1: 1000 \\
23,6\end{array}$ \\
\hline $\begin{array}{c}{\text { Vaccine } 02^{\mathrm{d}}} \\
\text { Dilution } \\
\text { ng OMV protein/ Kg rabbit }\end{array}$ & Pass & $\begin{array}{l}\text { Pass } \\
1: 1000 \\
47,4\end{array}$ \\
\hline $\begin{array}{c}\text { Vaccine } 03^{\mathrm{e}} \\
\text { Dilution } \\
\text { ng OMV protein/ Kg rabbit }\end{array}$ & Pass & $\begin{array}{l}\text { Pass } \\
1: 2000 \\
49,3\end{array}$ \\
\hline $\begin{array}{c}\text { VAMENGOC-BC }^{\circledR} \\
\text { Dilution } \\
\text { ng OMV protein/ Kg rabbit }\end{array}$ & Pass & $\begin{array}{l}\text { Pass } \\
1: 4000 \\
12,5\end{array}$ \\
\hline $\begin{array}{l}\text { DTP vaccine } \\
\text { Dilution }\end{array}$ & Pass & $\begin{array}{l}\text { Pass } \\
1: 4000 \\
12,5\end{array}$ \\
\hline $\begin{array}{c}\text { raw LOS } \\
50 \text { 000ugLOS/ Kg rabbit }\end{array}$ & Not applied & $\begin{array}{l}\text { Not } \\
\text { Tested }\end{array}$ \\
\hline $\begin{array}{l}\text { Detoxified LOS (dLOS) } \\
\text { Dilution after } 120 \text { min of } \\
\text { NaOH treatment }\end{array}$ & Not applied & $\begin{array}{c}\text { Pass } \\
1: 200 \\
500 \mathrm{ng} / \mathrm{Kg} \text { rabbit }\end{array}$ \\
\hline $\begin{array}{l}\text { Detoxified LOS (dLOS) } \\
\text { Dilution after } 150 \text { min of } \\
\mathrm{NaOH} \text { treatment }\end{array}$ & Not applied & $\begin{array}{c}\text { Pass } \\
1: 100 \\
500 \mathrm{ng} / \mathrm{Kg} \text { rabbit } \\
\text { Pass } \\
\end{array}$ \\
\hline
\end{tabular}

355 The iron starvation strategy for vaccine strain growth induced IRP expression in OMV outer 356 membrane from both vaccine strains in the molecular weight range between 60 and 90kDa. 357 Por A and other class proteins were well expressed in OMV from N44/89 and N603/95 (Figure $3)$.

Figure 3: Sodium dodecyl sulfate-polyacrylamide gel electrophoresis (10 $\mu \mathrm{g} / \mathrm{outer}$ membrane vesicle [OMV] protein) protein profile of vaccine strains OMV (A) N603/95 and (B) N44/89. Molecular weight (MW); (NP) OMV before sodium deoxy cholate (DOC) treatment; (P) OMV after DOC treatment; (BF) vaccine bulk before sterile filtration; (AF) vaccine bulk after sterile filtration.

364 Table 5 shows the percentages of expression of the main OMV proteins of the vaccine strains used as reproducibility parameter of the production process of this vaccine component. 
bioRxiv preprint doi: https://doi.org/10.1101/2021.08.13.456295; this version posted August 13,2021 . The copyright holder for this preprint

(which was not certified by peer review) is the author/funder, who has granted bioRxiv a license to display the preprint in perpetuity. It is made available under aCC-BY 4.0 International license.

Table 5: Class protein proportion (\%) of vaccine bulk after sterile filtration by densitometry

\begin{tabular}{c|c|c}
\hline Protein (\%) & $\mathbf{N 4 4 / 8 9}$ & $\mathbf{N 6 0 3 / 9 5}$ \\
\hline Por A & 23.54 & 8.10 \\
\hline Por B & 28.84 & 15.26 \\
\hline Class 4 & 7.63 & 1.94 \\
\hline Class 5 & 15.95 & 9.67 \\
\hline
\end{tabular}

369 The structural changes in Lipid A from raw LOS after the $\mathrm{NaOH}$ treatment are shown in the

370 SDS profiles. Both molecules had two bands but the molecular weights of dLOS were lower

371 than those shown in LOS profile before alkali detoxification (Figure 4).

372 Figure 4: Sodium dodecyl sulfate-polyacrylamide gel electrophoresis lipooligosaccharide

373 (LOS) profile from N44/89 biomass. MW, protein molecular weight standards of 16.949-2.512

$374 \mathrm{kDa}$; LOS, native endotoxin; dLOS, detoxified endotoxin.

\section{DISCUSSION}

376 The poor immunogenicity of serogroup B polysaccharide has focused on the study of

377 subcapsular antigens as an alternative approach to have an effective vaccine against

378 meningococcal disease caused by this serogroup [10,11, 33].

379 In countries in which meningococcal disease is caused by a specific strain of meningococcus

380 B, OMV vaccines have been shown to be effective. Their serotype specificity restricts the 381 induction of cross-immunity among the wide variety of pathogenic strains of this serogroup indicating the preferred use of these products for outbreaks control [34]. The OMV vaccines 
induce protective antibodies mainly against Por A, considered their major immunodominant antigen, which is the main target for SBA activity. The vaccine high efficacy is dependent of other outer membrane proteins and LOS, acting synergistically with Por A can contribute with vaccine efficacy $[35,36]$. The use of native OMV conformation as vaccine component, requires a detergent treatment to decrease LOS concentration aiming its decrease toxicity. LOS is an additional subcapsular antigen in OMV and has been studied to broaden coverage and crossreactivity of serogroup B meningococcal vaccines (zolliner).Despite successfully decreasing toxicity, the outer membrane components that contribute to induce the immune response can also be affected. It was very important the establishment of all physico-chemical controls of vaccine components according to the literature, that will presented to Brazilian regulatory agency to go forwards in clinical trials (Table 1),

The Brazilian vaccine against N.meningitidis serogroup B has in its composition, outer membrane vesicles (OMV) from Brazilian prevalent strains. They were obtained from bacteria growth with free iron starvation using ethylene diamine-di-(O-hydroxy-phenylacetic acid) (EDDHA) as iron chelator. This approach aimed to simulate the condition of availability of free iron in the blood of human host. The EDDHA chelating and release iron constants are similar to transferrin constants, which is the protein carrier of this element, in the blood. The presence of iron attached to protein carriers or EDDHA in bioreactor, induces the expression of iron 402 regulated proteins (IRPs) on N.meningitidis OMV membrane that may be important in 403 vaccine-induced immune response and increase of bacteria pathogenicity. Outer membrane 404 from B.pertussis obtained from growth under iron starvation conditions, showed higher expression of proteins regulated by this ion as well as decrease in LPS phosphorylation degree compared to standard molecule $[37,38,39,40]$. 
The mass spectrometry data showed a severe reduction of mass comparing native and detoxified partial hydrolysis of phospho groups, which generated a less toxic molecule (Figure 1).

Detergent-treated OMVs mainly induce immune response to parental strains homologous to

Por A, which provides limited cross-protection of these vaccines to different serosubtypes and serogroups. The expectation of an increase in vaccine cross-reactivity using LOS as additional component was based on previous studies. The L3, 7, and 8 Brazilian prevalent strain immunotypes are expressed on a high percentage of serogroup B strains associated with epidemics [41]. The expectation of an increase in vaccine cross-reactivity using LOS as additional component must be evaluated in human clinical trials of the developed vaccine [42]. A significant increase in total IgG to OMV was observed, in mice, for both vaccine strains after immunization with the three experimental preparations, compared to pre immune values. It can be used as a primary vaccine potency control parameter. There was no difference between three vaccine concentrations. Total IgG produced against LOS increased 15 days after the third dose only for the most concentrated vaccines. Moreover, the increase was concentration-dependent, as the highest LOS concentration induced the highest total IgG concentration. Total IgG produced against LOS did not indicate a different role for residual LOS on OMVs and added dLOS in the vaccine immune response (Table 2). The role of each of these molecules in inducing a protective response against meningococcus should be evaluated in human clinical studies.

However the use of LOS as vaccine component, demands de decrease of its toxicity not to increase OMV intrinsically pirogenicity. $\mathrm{A} \mathrm{NaOH}$ treatment is required to remove the esterlinked fatty acid tails from lipid A, which are responsible for the toxicity. dLOS as a potential target of serogroup B meningococcal vaccines is based on its contribution in bactericidal and 
OMV vaccines $[36,37,38]$. The samples of LOS and dLOS were analyzed by SDS-PAGE, analysis (Figure 2).

The SBA titers to N44/89 induced in mice were protective after the first dose and remained protective for 15 days after the third dose of all preparations with no increase after the third dose. On the other hand, the SBA titers to the N603/95 strain were protective only after the second dose, suggesting that the third dose was important. In addition, the N603/95 titers were significantly lower than for N44/89 using all vaccines. The values remained at lower levels for 15 days after the third dose (Table 3).

Human and murine-specific protecting antibodies are mainly directed against two long, hypervariable, extracellular regions in Por A loops 1 and 4. However, other minor proteins and LOS are antigens in the total immune response induced by OMV vaccines. Although Por A is the dominant antigen, other outer membrane components may act synergistically during the induced immune response against meningococcal B. Antibody affinity maturation was induced in response to the dominant antigen but was seriously delayed in response to a subdominant antigen, resulting in less functional serum IgG. The expression of minor proteins and their localization in the outer membrane are mandatory to activate the complement cascade via the classical pathway, which is the first step to eliminate the bacteria [35]. The Por A from N603/95 during the immune response to the experimental vaccines, which may contributed to SBA lower titres to N603/95 strain. The weaker immune response observed to the N603/95 strain may have been caused by weaker or less accessibility of $\mathrm{B}$ cell epitopes due to physical and chemical properties, such as hydrophobicity, length, or the combination of OMVs from the vaccine 
457 The Brazilian vaccine development approach, uses multiple antigens from B prevalent strains

458 with the aim of broading vaccine coverage (Figure 3 and 4). The combination of prevalent vaccine strains with different PorA (P1.19.15 and P1.7.1 from N44/89 and N603/95

460 respectively), and LOS immunotypes 3, 7, and 8, shared among different B strain serosubtypes

461 followed the tailor-made vaccine concept based on Brazilian meningococcal disease epidemiology [41].

The rabbit pyrogen test has been used historically to measure pyrogenicity potential of human and animal vaccines. However, whole cell and OMV based vaccines, which intrinsically contain relatively high concentration of pyrogenic material, has been a source of great concern. Several studies have been reported to define the best biological tests that can be used as safety parameters for clinical trial [43].

The pyrogenicity evaluation of OMV based vaccines has been shown that the way of production of these structures as well as the characteristics of the rabbit's strains can affect the test response what has hampered the establishment of the acceptable safety range for new vaccines, in the pyrogen test "in vivo". Although the results showed here are based on protein concentration, the minimum pyrogenic dose established in pirogenio test "in vivo" considers all pyrogens. In this way, to experimental vaccines are being considered all vaccine components contributing to the "in vivo" pyrogen test results $[9,10]$.

Experimental vaccines showed minimum pyrogenic dose between 23 and $50 \mathrm{ng}$ of protein per rabbit body weight. The differences observed for the vaccine with $25 \mathrm{ug}$ and 50ug of OMV protein $/ \mathrm{mL}$ can be attributed to inherent "in vivo" pyrogenic test variation. Although the vaccine with the highest concentration $(100 \mathrm{ug} / \mathrm{mL}$ protein), also presented $50 \mathrm{ng}$ ng of protein 479 per rabbit body weight as minimum pyrogenic dose, it was achieved with double dilution compared to vaccines with lower concentration of OMV protein. The results suggested that 
OMV concentrations higher than 50ng of protein per kg of rabbit body weight, the pyrogenicity activity seems to concentration dependent (Table 4).

Most of OMV based vaccines clinical studies, used 50 or $100 \mu \mathrm{g}$ of OMV protein $/ \mathrm{mL}$ but none of them, combining dLOS and OMVs from two strains, as the Brazilian B vaccine $[33,34]$. In the Brazilian developed vaccines, residual LOS from OMVs, plus dLOS from the N44/89 strain composed the total amount of LOS. To assess the contribution of dLOS in experimental preparations, it was also evaluated in the pyrogenic test "in vivo". The test performed with raw and detoxified LOS showed a decrease of $1 \times 10^{6}$ in LOS pyrogenicity activity which may attributed to de Liped A desacetillation $[9,10]$.

In the development of the Brazilian vaccine against meningococcus B, as for other producers, we used as a reference the WHO requeriments for meningococcal polysaccharide vaccines. The vaccine should be approved in rabbit pirogen test, in the dilution of 1:4000 of human-dose or $25 \mathrm{ng}$ polysaccharide/rabbit $\mathrm{kg}$ body weight as the minimum pyrogenic dose of N.meningitidis polysaccharide. According to what was established by the WHO, all tested vaccines would be safe for clinical trials in humans as they have passed the pyrogenicity test in rabbits at dilutions less than 1: 4000 of the probable human dose.The OMV-based vaccine, VAMENGOC-BC ${ }^{\circledR}$, and the DTP vaccine officially included in Brazilian Immunization Program calendar were used as references in the "in vivo" pyrogenic test to compare the experimental vaccine pyrogenic potential. Both vaccines, would be approved by WHO for clinical trials. However, their potential pyrogenicity were higher than what was observed for the three experimental vaccines in rabbits [44]. 
505 the OMVs was $5-10 \mu \mathrm{g} / 100 \mu \mathrm{g}$ total protein, which is in accordance with previous studies $506[45,46,47]$.

507 These study results indicate that the use of the Brazilian meningococcal B tested vaccines are

508 in accordance with the literature for similar products and clinical trials studies can be

509 considered.

510 CONFLIT OF INTEREST

511 All authors have no conflict of interest to declare.

512

513 ACKNOWLEDGMENTS

514 We would like to thank Dr. Carl Edward Frasch and Dr Akira Homma for their support and

515 guidance. This manuscript would not be possible without your contributions.

\section{AUTHOR CONTRIBUTIONS}

517 All authors contributed equally in the elaboration of this article. 


\section{Bibliography}

1 - Safadi MA, Cintra OA. Epidemiology of meningococcal disease in Latin America: current situation and opportunities for prevention. Neurol Res. 2010;32:263-71. DOI: $\underline{10.1179 / 016164110 X 12644252260754}$

2 - Safadi MA, Gonzalez-Ayala S, Jakel A, Wieffer H, Moreno C, Vyse A. The epidemiology of meningococcal disease in Latin America 1945-2010: an unpredictable and changing landscape. Epidemiol Infect. 2013;141:447-58. DOI: 10.1017/S0950268812001689

3 - de Filippis I, de Andrade CF, Silva L, Prevots DR, Vicente AC. PorA variable antigenic regions VR1, VR2, and VR3 of Neisseria meningitidis serogroups B and C isolated in Brazil from 1999 to 2004. Infect Immun. 2007;75:3683-5. DOI: 10.1128/IAI.01721-06

4 - de Filippis I, de Lemos AP, Hostetler JB, Wollenberg K, Sacchi CT, Dunning Hotopp JC, et al. Molecular epidemiology of Neisseria meningitidis serogroup B in Brazil. PLoS One. 2012;7:e33016. DOI: 10.1371/journal.pone.0033016

5 - Lemos AP, Harrison LH, Lenser M, Sacchi CT. Phenotypic and molecular characterization of invasive serogroup W135 Neisseria meningitidis strains from 1990 to 2005 in Brazil. J Infect. 2010;60:209-17. DOI:10.1016/j.jinf.2009.11.014

6 - de Moraes JC, Perkins BA, Camargo MC, Hidalgo NT, Barbosa HA, Sacchi CT, et al. Protective efficacy of a serogroup B meningococcal vaccine in Sao Paulo, Brazil. Lancet. 1992;340:1074-8. DOI:10.1016/0140-6736(92)93086-3

7 - Milagres LG, Ramos SR, Sacchi CT, Melles CE, Vieira VS, Sato H, et al. Immune response of Brazilian children to a Neisseria meningitidis serogroup B outer membrane protein vaccine: comparison with efficacy. Infect Immun. 1994;62:4419-24.

8 - Noronha CP, Struchiner CJ, Halloran ME. Assessment of the direct effectiveness of BC meningococcal vaccine in Rio de Janeiro, Brazil: a case-control study. Int J Epidemiol. 1995;24:1050-7. DOI:10.1093/ije/24.5.1050

9 - Zollinger WD, Moran EE, Schmiel DH. Characterization of an Antibody Depletion Assay for Analysis of Bactericidal Antibody Specificity. Clinical and Vaccine Immunology. 2009;16(12):1789-85. DOI:10.1128/CVI.00255-09

10 - Zollinger WD, Donets MA, Schmiel DH, Pinto VB, Labrie III JE, Moran EE, Brandt BL, Ionin B, Marques R, Wu M, Chen P, Stoddard MB, Keiser PB. Design and evaluation in mice of a broadly protective meningococcal groupB native outer membrane vesicle vaccine. Vaccine.2010;28:5057-5067. DOI:10.1016/j.vaccine.2010.05.006

11 - Jessouroun E, da Silveira IF, Larangeira AP, Pereira S, Fernandes SA, Rabinovitch L, et al. Outer membrane vesicles (OMVs) and detoxified lipooligosaccharide (dLOS) obtained from Brazilian prevalent $N$. meningitidis serogroup B strains protect mice against homologous and heterologous meningococcal infection and septic shock. Vaccine. 2004;22:2617-25. DOI: $\underline{10.1016 / j . v a c c i n e .2003 .12 .009}$

12 - Fredriksen JH, Rosenqvist E, Wedege E, Bryn K, Bjune G, Froholm LO, et al. Production, characterization and control of MenB-vaccine "Folkehelsa": an outer membrane vesicle vaccine against group B meningococcal disease. NIPH Ann. 1991;14:67-79; discussion 79-80. 
13 - Sierra GV, Campa HC, Varcacel NM, Garcia IL, Izquierdo PL, Sotolongo PF, et al. Vaccine against group B Neisseria meningitidis: protection trial and mass vaccination results in Cuba. NIPH Ann. 1991;14:195-207; discussion 8-10.

14 - Fu J, Bailey FJ, King JJ, Parker CB, Robinett RS, Kolodin DG, et al. Recent advances in the large scale fermentation of Neisseria meningitidis group B for the production of an outer membrane protein complex. Biotechnology (N Y). 1995;13:170-4. DOI:10.1038/nbt0295-170

15 - Tsai CM;Frasch CE; River E and Hochstein HD. Measurements of lipopolysaccharide (endotoxin) in meningococcal protein and polysaccharide preparation for vaccine usage. J Biol Stand, 1989, 17, 249-258.

16 - Westphal O and Jann K. Bacterial lipopolysaccharides: extraction with phenol-water and further applications of the procedure. Meth Carboh Chem. 1965;83-9.

17 - Wollenweber H-W, Rietschel ET. Analysis of lipopolysaccharide (lipid A) fatty acids. Journal of Microbiological Methods. 1990;11:195-211. DOI:10.1016/0167-7012(90)90056-C

18 - Estabrook MM, Jarvis GA, McLeod Griffiss J. Affinity-purified human immunoglobulin $\mathrm{G}$ that binds a lacto-N-neotetraose-dependent lipooligosaccharide structure is bactericidal for serogroup B Neisseria meningitidis. Infect Immun. 2007;75:1025-33. DOI:10.1128/IAI.00882$\underline{06}$

19 - Rosenqvist E, Kayhty H, Pollard AJ. Determination of antibody responses to meningococcal antigens by ELISA. Methods Mol Med. 2001;66:255-73. DOI:10.1385/1$\underline{\text { 59259-148-5:255 }}$

20 - Borrow R, Aaberge IS, Santos GF, Eudey TL, Oster P, Glennie A, et al. Interlaboratory standardization of the measurement of serum bactericidal activity by using human complement against meningococcal serogroup b, strain 44/76-SL, before and after vaccination with the Norwegian MenBvac outer membrane vesicle vaccine. Clin Diagn Lab Immunol. 2005;12:97076. DOI:10.1128/CDLI.12.8.970-976.2005

21 - Borrow R, Carlone GM, Rosenstein N, Blake M, Feavers I, Martin D, et al. Neisseria meningitidis group B correlates of protection and assay standardization--international meeting report Emory University, Atlanta, Georgia, United States, 16-17 March 2005. Vaccine. 2006;24:5093-107. DOI:10.1016/j.vaccine.2006.03.091

22 - Abnormal Toxicity. In: European Pharmacopoeia 2011, 7th Edition, Chapter 2, Section 2.6.9: p. 162 .

23 - Microbiological Tests/Sterility Tests. In: The United States Pharmacopeia 30 NF $25<71>$ 2007: p. 97-102.

24 - Markwell MA, Haas SM, Bieber LL, Tolbert NE. A modification of the Lowry procedure to simplify protein determination in membrane and lipoprotein samples. Anal Biochem. 1978;87:206-10. DOI:10.1016/0003-2697(78)90586-9

25 - Laemmli UK. Cleavage of structural proteins during the assembly of the head of bacteriophage T4. Nature. 1970;227:680-5. 
26 - Fomsgaard A, Freudenberg MA, Galanos C. Modification of the silver staining technique to detect lipopolysaccharide in polyacrylamide gels. J Clin Microbiol. 1990;28:2627-31.

27 - Li J, Richards JC. Application of capillary electrophoresis mass spectrometry to the characterization of bacterial lipopolysaccharides. Mass Spectrom Rev. 2007;26:35-50. DOI: $\underline{10.1002 / m a s .20105}$

28 - Osborn MJ. Studies on the Gram-Negative Cell Wall. I. Evidence for the Role of 2-Keto3-Deoxyoctonate in the Lipopolysaccharide of Salmonella Typhimurium. Proc Natl Acad Sci USA. 1963;50:499-506. DOI:10.1073/pnas.50.3.499

29 - Fogel R, Garcia RR, da Silva Oliveira R, Palacio DN, da Silva Madeira L, Pereira N. Optimization of acid hydrolysis of sugar cane bagasse and investigations on its fermentability for the production of xylitol by Candida guilliermondii. Appl Biochem Biotechnol. 2005;121124:741-52. DOI:10.1385/abab:122:1-3:0741

30 - Bjerre A, Brusletto B, Rosenqvist E, Namork E, Kierulf P, Ovstebo R, et al. Cellular activating properties and morphology of membrane-bound and purified meningococcal lipopolysaccharide. J Endotoxin Res. 2000;437-45.DOI: 10.1177/09680519000060060501

31 - Svennerholm L. Quantitative estimation of sialic acids. II. A colorimetric resorcinolhydrochloric acid method. Biochim Biophys Acta. 1957;24:604-11. DOI:10.1016/00063002(57)90254-8

\section{2 - European Pharmacopoeia, 2016}

33 - Holst J, Oster P, Arnold R, Tatley MV, Naess LM, Aaberge IS, et al. Vaccines against meningococcal serogroup B disease containing outer membrane vesicles (OMV): lessons from past programs and implications for the future. Hum Vaccin Immunother. 2013;9:1241-53. DOI: $\underline{10.4161 / h v .24129}$

34 - Holst J, Martin D, Arnold R, Huergo CC, Oster P, O'Hallahan J, et al. Properties and clinical performance of vaccines containing outer membrane vesicles from Neisseria meningitidis. Vaccine. 2009;27 Suppl 2:B3-12. DOI:10.1016/j.vaccine.2009.04.071

35 - Weynants VE, Feron CM, Goraj KK, Bos MP, Denoel PA, Verlant VG, et al. Additive and synergistic bactericidal activity of antibodies directed against minor outer membrane proteins of Neisseria meningitidis. Infect Immun. 2007;75:5434-42. DOI: 10.1128/IAI.00411-07

36 - Frasch CE, Borrow R, Donnely J, Bactericidal antibody is the immunologic surrogate of protection against meningococcal disease. Vaccine 27S, 2009, B112-B116. DOI:10.1016/j.vaccine.2009.04.065

37 - Aisen P, Leibman A, and Zweier J. Stoichiometric and site characteristics of the binding of iron to human transferrin. J Biol Chem.1978;253 (6): 1930-1937.

38 - Agiato LA and Dyer DW. Siderophore Production and Membrane Alterations by Bordetella pertussis in Response to Iron Starvation. Infection and Immunity. 1992;60 (1):117123.

39 - Brandileone MCC, ZanellaRC, Vieira VSD,Sacchi CT, Milagres LG, Frasch CE. Induction of iron regulated proteins during normal growth of Neisseria meningitidis in a chemically 
636 defined médium. Rev.Inst.Med.Trop., São Paulo. 1994; 36(4):301-310. DOI:10.1590/s0036-

$637 \underline{46651994000400002}$

63840 - Kean MA, Delgado EB, Mensink BP, Bugter MHJ. Iron chelating agents and their effects 639 on the growth of Pseudokirchneriella subcapitata, Chlorella vulgaris, Phaeodactylum 640 tricornutum and Spirulina platensis in comparison to Fe- EDTA. J. Algal Biomass Utln. 2015; $6416(1): 56-73$.

64241 - Epidemiologic Surveillance Center (Brazil). Respiratory transmitted diseases. Available 643 at: $<$ http://www.cve.saude.sp.gov.br/> [Accessed 2016 June 06].

64442 - Griffiss JM, Brandt BL, Saunders NB, Zollinger W. Structural Relationships and 645 Sialylation among Meningococcal L1, L8, and L3,7 Lipooligosaccharide Serotypes. J Biol 646 Chem. 2000;275(13):9716-24.

64743 - Vipond C, Findlay L, Feavers I, Care R. Limitations of the rabbit pyrogen Test for assessing 648 meningococcal OMV based Vaccines.2016 Alex 33(1): 47-53. DOI:10.14573/altex.1509291

64944 - World Health Organization. Recommendations for the production and control of 650 meningococcal group C conjugate vaccines. WHO Technical Report Series No. 924;2004.

65145 - Kaaijk P, van Straaten I, van de Waterbeemd B, Boot EP, Levels LM, van Dijken HH, et 652 al. Preclinical safety and immunogenicity evaluation of a nonavalent PorA native outer 653 membrane vesicle vaccine against serogroup $B$ meningococcal disease. Vaccine. 654 2013;31:1065-71. DOI:10.1016/j.vaccine.2012.12.031

65546 - Pinto VB, Burden R, Wagner A, Moran EE, Lee CH. The development of an experimental 656 multiple serogroups vaccine for Neisseria meningitidis. PLoS One. 2013;8:e79304. 657 DOI: $10.1371 /$ journal.pone.0079304 


\section{Supporting information}

660 S1 - Figure 1: Electrospray ionization/mass spectroscopy (ESI/MS) of O-deacylated 661 lipooligosaccharide (LOS) from N44/89 Neisseria meningitidis B, strain.

\section{2 (File: Figure 1 PLos One Ellen Jessouroun.tif)}

663 S2 - Figure 2: Electron microscopy of outer membrane vesicles (OMV) from the N44/89 strain $664(1 \mathrm{mg} / \mathrm{mL})$ in distilled water negatively stained with $0.5 \%(\mathrm{w} / \mathrm{v})$ phosphotungstic acid, $\mathrm{pH} 7.0$ 665 The preparations were examined under an electron microscope (JEM 1010; Jeol, Tokyo, Japan).

\section{6 (File: Figure 2 PLOs One Ellen Jessouroun_300dpi.tif)}

667 S3 - Figure 3: Sodium dodecyl sulfate-polyacrylamide gel electrophoresis (10 $\mu \mathrm{g} / \mathrm{outer}$ membrane vesicle [OMV] protein) protein profile of vaccine strains OMV (A) N603/95 and (B) N44/89. Molecular weight (MW); (NP) OMV before sodium deoxy cholate (DOC) treatment; (P) OMV after DOC treatment; $(\mathrm{BF})$ vaccine bulk before sterile filtration; (AF)

671 vaccine bulk after sterile filtration. 
bioRxiv preprint doi: https://doi.org/10.1101/2021.08.13.456295; this version posted August 13,2021 . The copyright holder for this preprint (which was not certified by peer review) is the author/funder, who has granted bioRxiv a license to display the preprint in perpetuity. It is made available under aCC-BY 4.0 International license.

673 Figure 4: Sodium dodecyl sulfate-polyacrylamide gel electrophoresis lipooligosaccharide

674 (LOS) profile from N44/89 biomass. MW, protein molecular weight standards of 16.949-2.512

$675 \mathrm{kDa}$; LOS, native endotoxin; dLOS, detoxified endotoxin.

676 (File: Figure 4 PLOs One Ellen Jessouroun.tiff) 


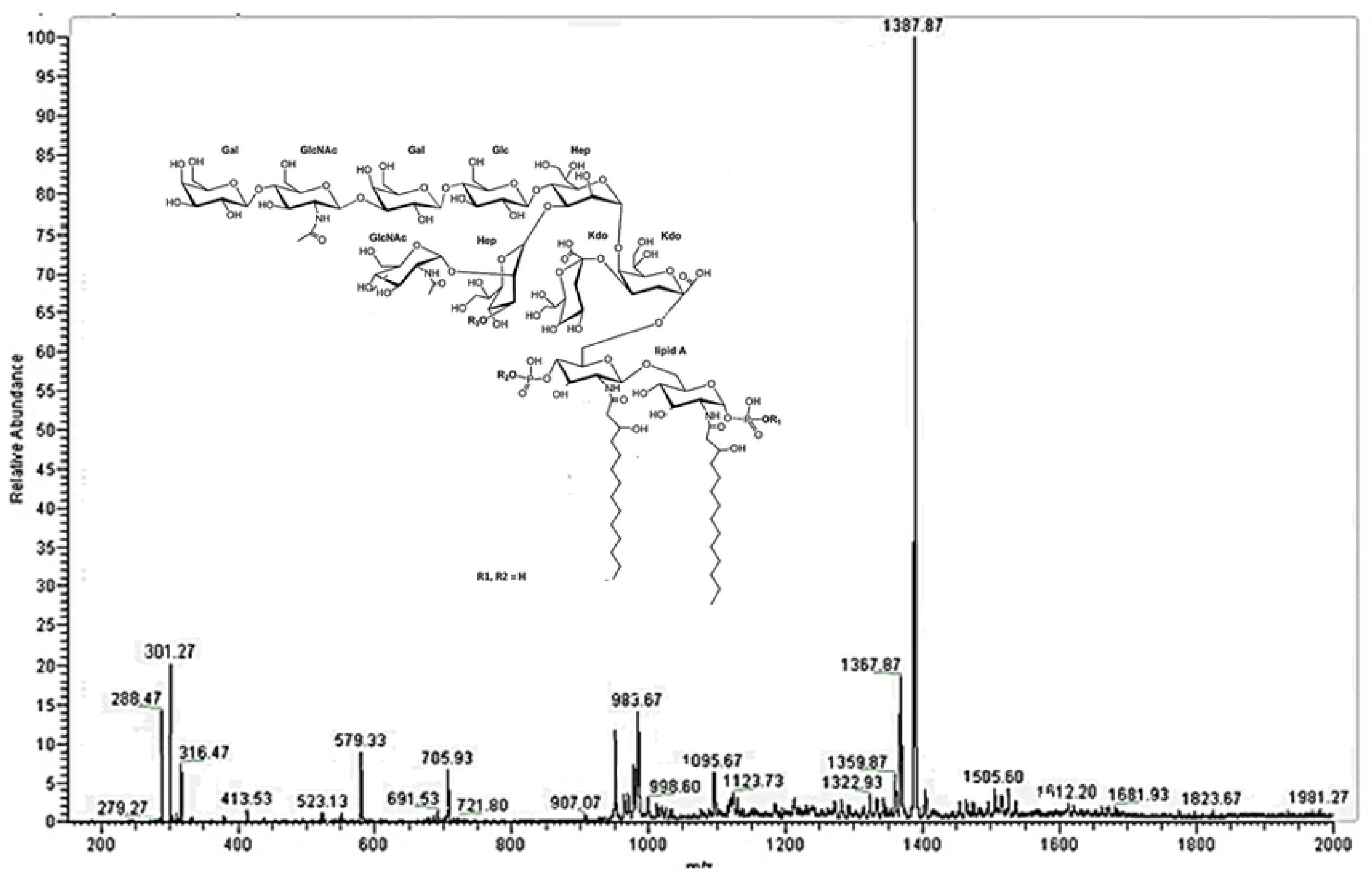

Figure 


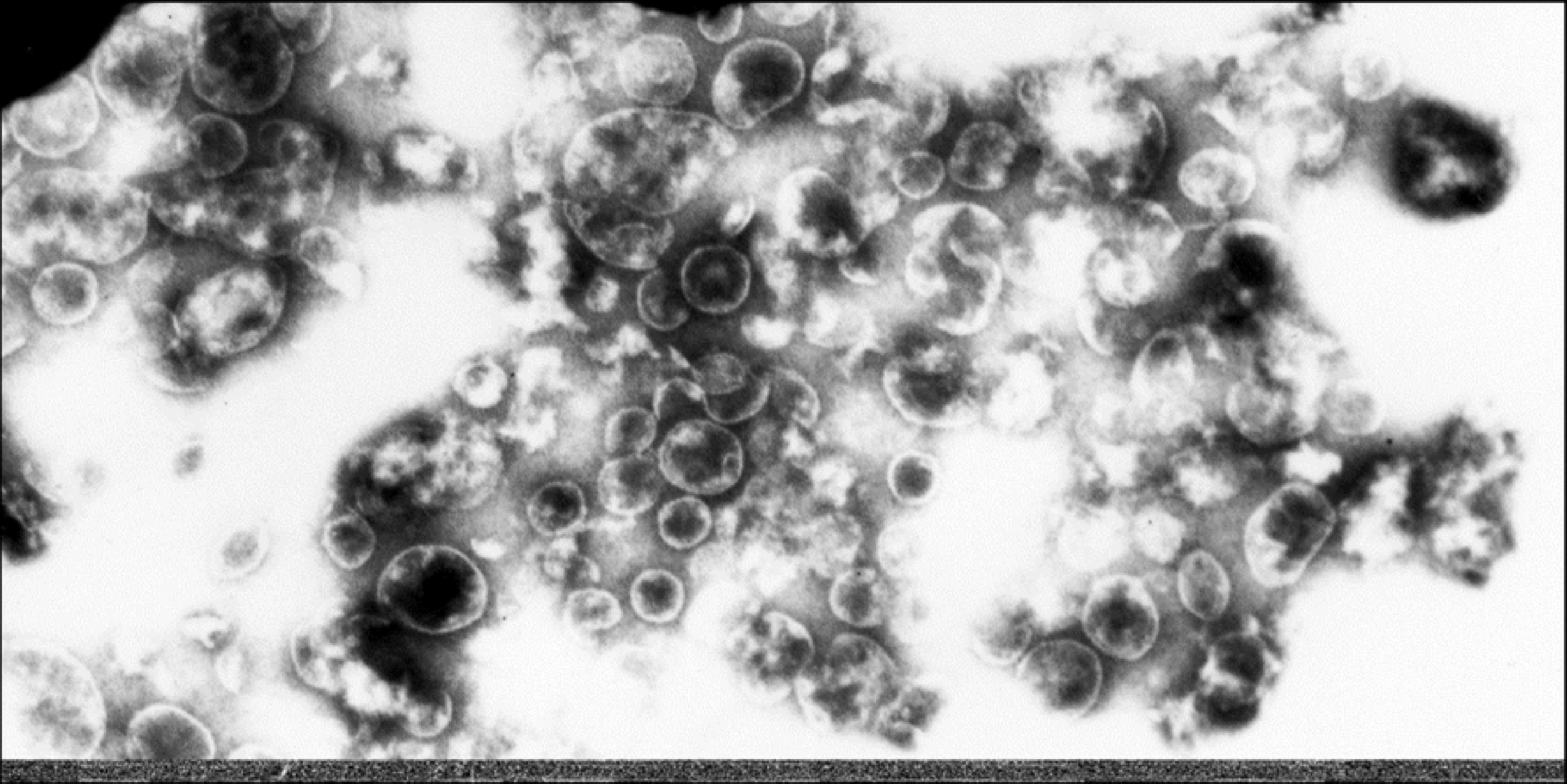

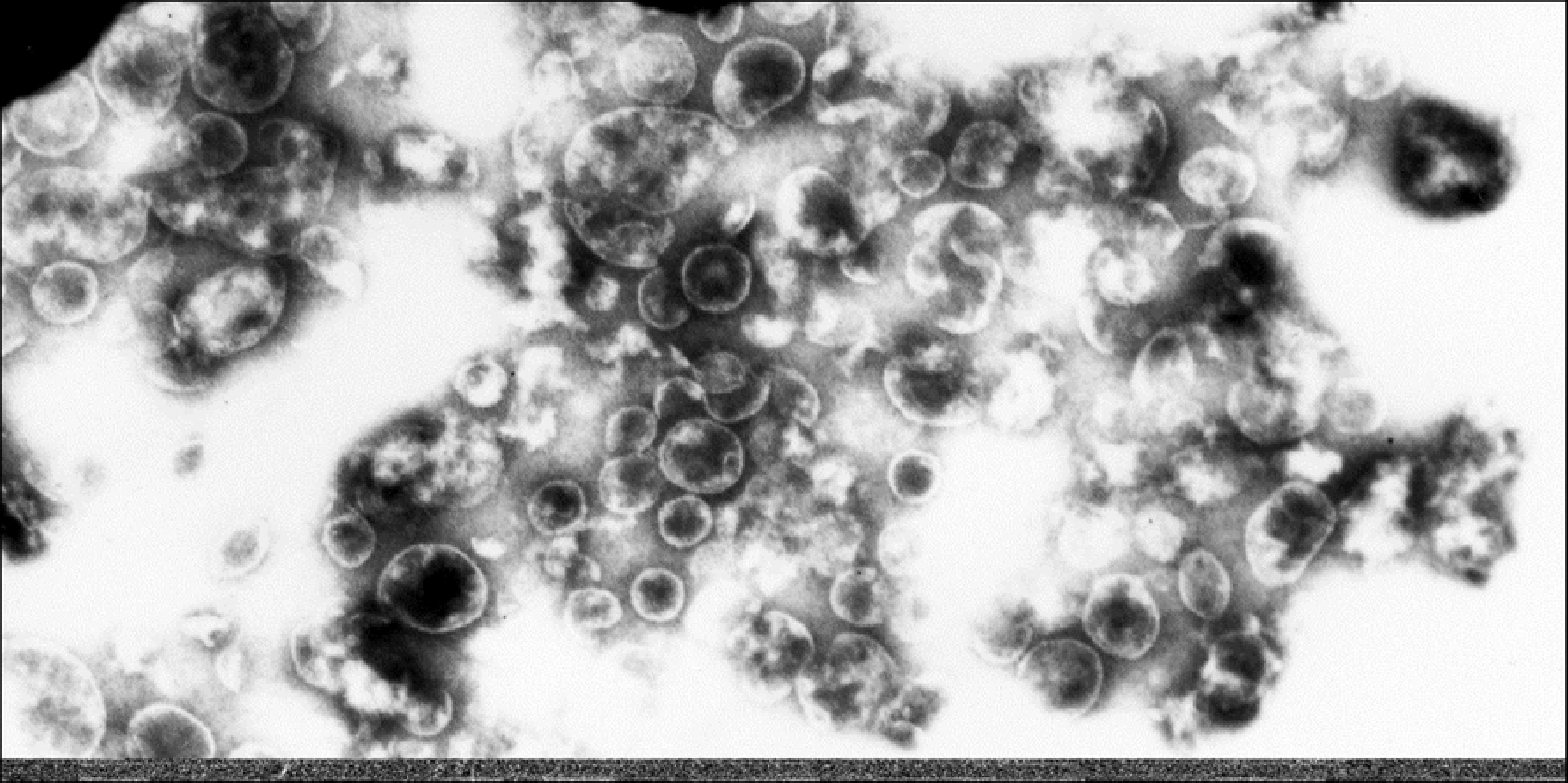
0.

\section{Figure}




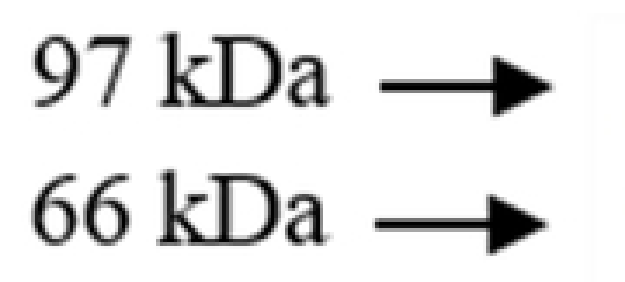

$45 \mathrm{kDa}$

$30 \mathrm{kDa} \longrightarrow$

\section{$20.1 \mathrm{kDa} \longrightarrow$}

bioRxiv preprint doi: https://doi.org/10.1101/2021.08.13.456295; this version posted August 13, 2021. The copyright holder for this preprint made available under aCC-BY 4.0 International license.
J IRPs

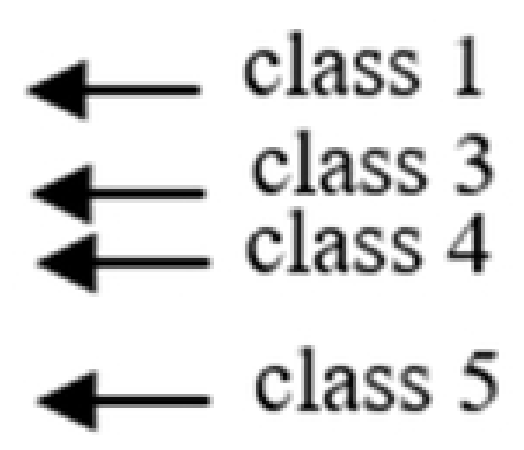

$14.4 \mathrm{kDa} \longrightarrow$

MW NP $\quad$ P $\quad$ BF $\quad$ AF

$97 \mathrm{kDa} \longrightarrow$

$66 \mathrm{kDa} \longrightarrow$

$45 \mathrm{kDa} \rightarrow$

$30 \mathrm{kDa}$

$20.1 \mathrm{kDa} \longrightarrow$

$14.4 \mathrm{kDa} \longrightarrow$
NP

$\mathrm{P}$

BF
J IRPs

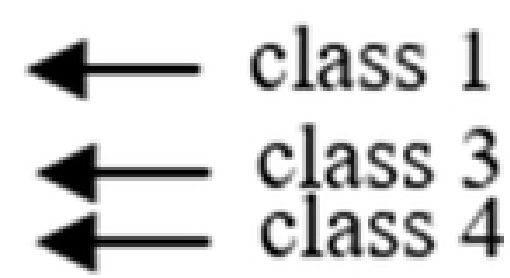

$\longleftarrow$ class 5

Figure 
$10700 \mathrm{kDa} \rightarrow$
$16949 \mathrm{kDa} \rightarrow$
$14404 \mathrm{kDa} \rightarrow$
$8159 \mathrm{kDa} \rightarrow$
$6214 \mathrm{kDa} \rightarrow$

MW

LOS dLOS

Figure 